\title{
Hematological Parameters in Severe Complicated Plasmodium falciparum Malaria among Adults in Aden
}

\author{
Ciddi Komplike Falciparum Sttmalı Aden Yetişkinlerinde \\ Hematolojik Parametreler
}

Sawsan Bakhubaira

Aden University, Faculty of Medicine and Health Sciences, Department of Hematology Oncology, Aden, Yemen

\begin{abstract}
:
Objective: To study some hematological parameters in adult patients with complicated severe malaria and their relations to clinical outcome.

Materials and Methods: This was a prospective study, including 77 patients from Aden Governorate with complicated severe malaria over the course of 2 years (2010-2011).

Results: The common form of severe malaria in Aden was cerebral malaria (25.9\%), followed by renal failure (18.2\%), severe anemia (16.9\%), and hepatitis (14.3\%), with a case fatality rate of $7.8 \%$. Hemoglobin concentration was significantly different among the various complications of severe malaria, while platelet and white blood cell counts did not show such differences. The mean age was older among patients that died. Hematological parameters did not significantly differ among dead or surviving patients. Thrombocytopenia was seen in $42.9 \%$ of patients and $18.2 \%$ of these had platelet counts of $<50.0 \times 10^{9} / \mathrm{L}$. However, none of them developed bleeding.
\end{abstract}

Conclusion: This study concluded that hematological changes are common complications encountered in severe malaria, but they are not related to the clinical outcome.

Key Words: Complicated, Severe, Malaria, Thrombocytopenia

Özet:

Amaç: Komplike ağır sıtmalı hastalarda bazı hematolojik parametrelerin klinik sonuç ile ilişkisinin incelenmesi.

Gereç ve Yöntemler: Aden vilayetinde iki yıllık sürede (2010-2012) tanı alan 77 komplike ağır sıtma hastasını içine alan prospektif bir çalışma yapıldı.

Bulgular: Ağır sıtmanın çeşitli komplikasyonlarında hemoglobin konsantrasyonları önemli ölçüde farklı idi, bununla birlikte trombosit ve lökosit sayıları bu farklılı̆̆ göstermedi. Yaş ortalaması ölen hastalar arasında büyüktü.

Hematolojik parametreler, ölen ya da hayatta kalan hastalar arasında önemli derecede farklı değildi. Trombositopeni oranı \%42,9 idi ve bunların \%18,2'sinde sayı 50,0 x109/L'den küçüktü. Ancak hiçbirinde kanama gelişmedi.

Sonuç: Bu çalışma ile, hematolojik değişikliklerin ağır sıtmada sık karşılaşılan komplikasyonlar olduğu fakat klinik sonuç ile ilişkili olmadığı sonucuna varılmıştır.

Anahtar Kelimeler: Komplike, Ciddi, Sitma, Trombositopeni

Address for Correspondence: Sawsan BAKHUBAİRA, M.D,

Aden University, Faculty of Medicine and Health Sciences, Department of Hematology Oncology, Aden, Yemen

Phone: 00967777929010 E-mail: bakhubaira@gmail.com

Received/Geliş tarihi : October 16, 2011

Accepted/Kabul tarihi : May 16, 2013 


\section{Introduction}

Malaria is an important cause of death and illness, especially in tropical countries [1]. The most severe forms of and deaths from malaria are caused by Plasmodium falciparum, with other species rarely producing serious complications, debilitating relapses, and even death [2]. Major complications of severe malaria can develop rapidly and progress to death within hours or days [3]. These include cerebral malaria, pulmonary edema, acute renal failure, severe anemia, and/or bleeding. Acidosis and hypoglycemia are the most common metabolic complications $[1,2,3,4]$.

The World Health Organization (WHO) established criteria for severe malaria that assisted clinical and epidemiological studies. This project was begun in 1990 [4] and was then revised in 2000 to include other clinical manifestations and laboratory values that portend a poor prognosis based on clinical experience in semi-immune patients [3].

In Yemen, malaria remains a significant health problem, with Plasmodium falciparum as the predominant species that is responsible for $90 \%$ of malaria cases [5]. Different studies were conducted on severe malaria, such as that of Al-Taiar et al. [6] on pediatric patients, which showed severe malaria constituting $17 \%$ of pediatric hospital admissions. In the same study, the main presentation of severe malaria was respiratory distress $(40 \%)$, followed by severe anemia (37\%) and cerebral malaria (8\%). Another study conducted by Al-Mekhlafi et al. [7] reported that severe malaria puts a high burden on health services in Yemen, and they found a high prevalence of severe malaria among children younger than 5 years old.

The previous studies on severe malaria in Yemen did not focus on the hematological parameters of complicated severe malaria in adults; therefore, this study was conducted to evaluate the main hematological parameters in adult patients with complicated severe malaria in Aden, where a large central referral hospital and a branch of the National Center of Public Health Laboratories (NCPHL) are present.

\section{Materials and Methods}

This was a prospective study that included 77 patients from Aden Governorate with complicated severe malaria admitted to Al-Gamhouria Modern General Hospital (Aden, Yemen) and treated at the NCPHL in Aden during 2 years (2010-2011). Patients were selected according to the following criteria: adult Yemeni patients with severe malaria (aged 18 years or more), confirmed to have Plasmodium falciparum malaria parasites in the peripheral blood or bone marrow, and presenting with severe malaria as according to the WHO definition [3]. Severe malaria patients were followed within the hospital until death or discharge (not including discharge against medical advice).
Exclusion criteria included severe malaria patients of $<18$ years of age, severe malaria patients who were not residents of Aden (because they usually refuse to stay in the hospital after initial improvement), and severe malaria patients who absconded or were discharged against medical advice.

The hematological data were collected from the NCPHL in Aden. The clinical data were obtained directly from patients or relatives as well as from physicians in the intensive care unit of the internal medical department of the hospital, where complicated severe malaria patients are admitted.

In the NCPHL, malaria is diagnosed by thick and thin blood films. These films were stained with Giemsa for the detection and characterization of Plasmodium falciparum malaria and the parasite load was determined for each film.

Diagnosis of severe malaria was established according to the WHO criteria published in 2000 [3]:

- Severe anemia was defined as normocytic normochromic anemia with hematocrit of $<15 \%$ or hemoglobin of $<5 \mathrm{~g} /$ $\mathrm{dL}$ in the presence of parasitemia at $>1000 / \mu \mathrm{L}$. In the case of microcytic/hypochromic anemia, iron deficiency, thalassemia, and hemoglobinopathy were ruled out.

- Cerebral malaria was defined as unrousable coma not attributable to any other cause, with a Glasgow Coma Scale score of $\leq 9$, or coma that persisted for at least 30 minutes after a generalized convulsion.

- Renal failure was defined as urine output of $<400 \mathrm{~mL} / 24$ $\mathrm{h}$ and serum creatinine of $>3.0 \mathrm{mg} / \mathrm{dL}$ despite adequate volume repletion.

- Circulatory collapse (algid malaria) was defined as systolic blood pressure of $<70 \mathrm{mmHg}$ with cold, clammy skin or a core-skin temperature difference of $>10^{\circ} \mathrm{C}$.

- Black-water fever was defined as the passage of dark red, brown, or black urine secondary to massive intravascular hemolysis and resulting hemoglobinuria.

- Hepatitis was defined as the presence of clinically detected jaundice with serum bilirubin concentration of $>3$ $\mathrm{mg} / \mathrm{dL}$ and ultrasonographic evidence of enlarged, inflamed liver with elevated liver enzymes.

- Hypoglycemia was defined as plasma glucose level of $<40 \mathrm{mg} / \mathrm{dL}$.

- Prostration and weakness was defined as a patient who could not sit or walk with no obvious neurological explanations.

\section{Statistical Analysis}

The collected data were analyzed with SPSS 18. Quantitative variables were presented as mean values, standard deviations, and ranges. Results were tested by the Mann-Whitney or Student t-test with a 95\% level of significance and $\mathrm{p} \leq 0.05$ was considered statistically significant. 


\section{Ethical Considerations}

This study was approved by the ethics committee of the hospital as well as by the ethics committee of the NCPHL in Aden. During data collection from patients or relatives, verbal consent was obtained, and names and personal data were completely secured and transferred to codes to keep patients' identities private.

\section{Results}

A total of 88 patients were diagnosed with complicated severe malaria, and 11 of these were excluded due to leaving the hospital early against medical advice. The remaining 77 patients were followed until discharge with medical advice or death.

The most common form of complicated severe malaria among the studied 77 patients in Aden was cerebral malaria (25.9\%), followed by renal failure, severe anemia, and hepatitis at $18.2 \%, 16.9 \%$, and $14.3 \%$, respectively (Table 1 ).

The mean hemoglobin concentration showed a highly significant statistical difference in relation to the type of complications in severe malaria $(\mathrm{p}=0.00001)$; it was lowest in those with severe anemia $(3.5 \mathrm{~g} / \mathrm{dL})$, increasing to $8.2 \mathrm{~g} /$ $\mathrm{dL}$ in cases of renal failure, to 9 and $9.1 \mathrm{~g} / \mathrm{dL}$ respectively in hepatitis cases and in prostrated patients, and up to 11.4 and $11.6 \mathrm{~g} / \mathrm{dL}$ in cerebral malaria and algid malaria patients, respectively (Table 1 ).

Platelet and white blood cell (WBC) counts did not show significant statistical differences in relation to the type of complications in severe malaria $(\mathrm{p}=0.052$ and $\mathrm{p}=0.095$, respectively) (Table 1).

The studied patients were followed until complete improvement and discharge, while 6 of them died, representing a case fatality rate of $7.8 \%$ (Figure 1 ). The mean age of deceased patients with severe malaria was statistically significantly older than the mean age of those who survived after severe malaria: 45.2 years versus 29.3 years, respectively $(\mathrm{p}=0.015)$. However, the mean values of the studied hematological parameters (hemoglobin, platelet, and WBC counts) were not significantly different among those who died or survived after severe complicated malaria (Table 2).

Thirty-three patients from the studied 77 with severe complicated malaria had thrombocytopenia (platelet count of $<150 \times 109 / \mathrm{L}$ ) at variable degrees; this rate represents $42.9 \%$ of all severe complicated malaria cases in this study. However, none of them developed bleeding. In these patients, the

Table 1. Studied hematological parameters by type of complications in severe malaria.

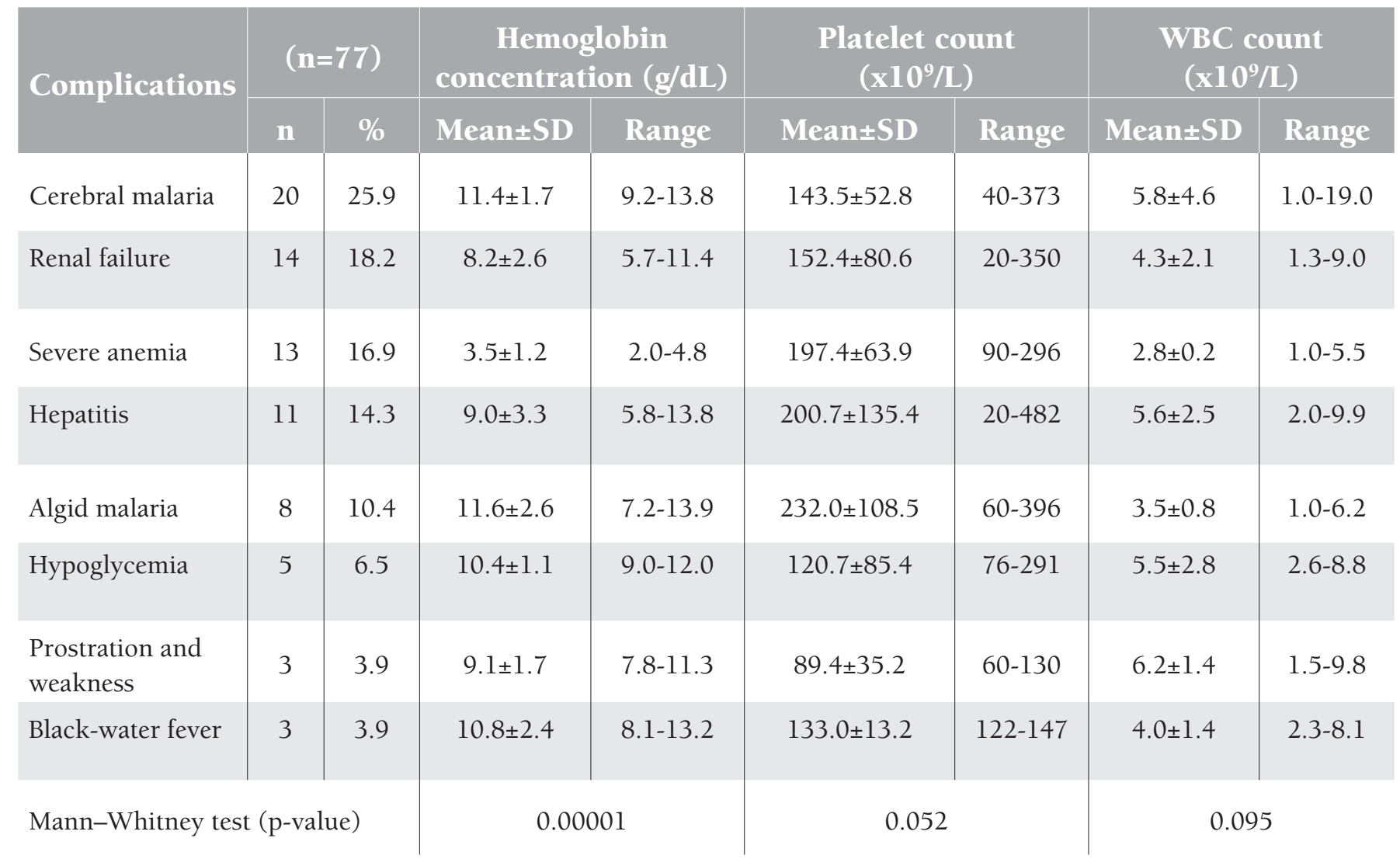

$\mathrm{p} \leq 0.05$ is statistically significant. SD: standard deviation; WBC: white blood cell. 
count was repeated by manual method. They were classified into 3 grades: grade 1 thrombocytopenia with counts of $<150$ to $75 \times 109 / \mathrm{L}$, grade 2 thrombocytopenia with counts of $<75$ to $50 \times 109 / \mathrm{L}$, and grade 3 thrombocytopenia with counts of $<50 \times 109 / \mathrm{L}$. The studied cases of thrombocytopenia were classified as $57.6 \%$ in grade $1,24.2 \%$ in grade 2 , and $18.2 \%$ in grade 3 (Table 3 ).

Three of the 6 deceased patients had grade 1 thrombocytopenia, 2 had grade 2 , and 1 had grade 3 (Table 3). Five out of the 6 deceased patients in this study (83.3\%) had cerebral malaria, while the sixth patient $(16.7 \%)$ had renal failure (Table 4).

\section{Discussion}

This study demonstrated some hematological parameters in complicated severe malaria due to Plasmodium falciparum, which is the most common type of malaria infection in Yemen, accounting for $90 \%$ of malaria cases [5].

Cerebral malaria was the most common complication in severe malaria in adults, representing a quarter of the studied cases $(25.9 \%)$. Several hypotheses have been proposed to explain the pathophysiology of cerebral malaria, but none have been completely satisfactory. Moreover, there is no association of cerebral malaria with altered hematological parameters [1]. This is similar to the findings of this study

Table 2. Age and studied hematological parameters of deceased versus surviving patients with complicated severe malaria.

\begin{tabular}{|c|c|c|c|c|c|}
\hline \multirow{2}{*}{$\begin{array}{l}\text { Hematological } \\
\text { parameters }\end{array}$} & \multicolumn{2}{|c|}{ Alive $(n=71)$} & \multicolumn{2}{|c|}{ Died $(n=6)$} & \multirow{2}{*}{$\mathbf{p}^{*}$} \\
\hline & Mean \pm SD & Range & Mean \pm SD & Range & \\
\hline Age (years) & $29.3 \pm 14.5$ & $18-70$ & $45.2 \pm 21.1$ & $19-80$ & 0.015 \\
\hline Hemoglobin concentration (g/dL) & $10.1 \pm 2.8$ & $3.2-13.9$ & $9.3 \pm 2.4$ & $2.0-12.2$ & 0.312 \\
\hline Platelet count (x109/L) & $131.9 \pm 85.8$ & $40-373$ & $140.5 \pm 67.1$ & $48-335$ & 0.812 \\
\hline WBC count $\left(\times 10^{9} / \mathrm{L}\right)$ & $4.2 \pm 2.7$ & $1.0-19.0$ & $3.4 \pm 1.4$ & $1.0-9.9$ & 0.477 \\
\hline
\end{tabular}

*: p-values were calculated by t-test. SD: standard deviation; WBC: white blood cell.

Table 3. Grades of thrombocytopenia associated with complicated severe malaria in adult patients in Aden.

\begin{tabular}{|c|c|c|c|c|c|c|}
\hline \multicolumn{2}{|c|}{ Thrombocytopenia } & \multirow{2}{*}{ n } & \multirow{2}{*}{$\%$} & \multirow{2}{*}{ Minimum } & \multirow{2}{*}{ Maximum } & \multirow{2}{*}{$\begin{array}{c}\text { Number of deceased } \\
\text { patients }\end{array}$} \\
\hline Grade & $\left(x 10^{9} / \mathrm{L}\right)$ & & & & & \\
\hline Grade 1 & $<150.0-75.0$ & 19 & 57.6 & 75.0 & 149.3 & 3 \\
\hline Grade 2 & $<75.0-50.0$ & 8 & 24.2 & 50.0 & 74.6 & 2 \\
\hline Grade 3 & $<50.0$ & 6 & 18.2 & 24.3 & 49.2 & 1 \\
\hline Total & & 33 & 100.0 & 24.3 & 149.3 & 6 \\
\hline
\end{tabular}


(Table 1), whereby mean hemoglobin, WBC, and platelet counts were not affected in cerebral malaria patients.

Hemoglobin concentration showed lowest mean values reaching $3.5 \mathrm{~g} / \mathrm{dL}$ in the studied patients with severe anemia. Plasmodium falciparum malaria is one of the most common causes of anemia. The other Plasmodium species rarely cause anemia because only select red cell populations (reticulocytes in the case of P. vivax and P. ovale and older cells in P. malariae) are invaded. Multiple mechanisms cause anemia in severe malaria, the most important being hemolysis of infected and uninfected red blood cells (RBCs), splenic sequestration of RBCs, dyserythropoiesis, and bone marrow suppression; such factors can culminate in the chronically low hemoglobin values observed in patients residing in holoendemic regions $[8,9]$.

Studies found that anemia is also correlated with the severity of malaria infection [10]. In this study, the mean WBC count did not show a deviation from the normal reference range in all types of complicated severe malaria. This is similar to the results reported by Bashawri et al. [11]

Table 4. Causes of mortality in 6 adult patients with complicated severe malaria in Aden.

\begin{tabular}{l|l|l}
\hline Cause of death & n & $\%$ \\
\hline $\begin{array}{l}\text { Cardiopulmonary arrest with cere- } \\
\text { bral malaria }\end{array}$ & 5 & 83.3 \\
$\begin{array}{l}\text { Cardiopulmonary arrest with renal } \\
\text { failure }\end{array}$ & 1 & 16.7 \\
\hline Total & 6 & 100.0
\end{tabular}

in Saudi Arabia. However, other studies showed that during severe P. falciparum infection there are changes in leukocyte proliferation and function.

Thrombocytopenia was detected in $42.9 \%$ of the studied patients with complicated severe malaria. This is a common hematological alteration in malaria, which may be a result of peripheral platelet destruction and consumption. Studies showed that immune complexes generated by malarial antigens lead to sequestration of the injured platelets by macrophages in the spleen [12]. The present finding of thrombocytopenia is similar to that that reported by Banzal et al. [13] in Saudi Arabia (50.4\%).

In this study, thrombocytopenia was graded to look for the percentage of lower platelet counts; $18.2 \%$ of the studied patients showed a count of $<50.0 \times 109 / \mathrm{L}$. In a study by Khan et al. [14], a quarter (26.8\%) of the cases of P. falciparum malaria showed grade 3 thrombocytopenia with a count of $<50.0 \times 109 / \mathrm{L}$. However, none of our patients bled, and all of them recovered from thrombocytopenia quickly during treatment.

In regard to mortality associated with complicated severe malaria, neurological manifestations were the major determinant of morbidity and mortality in severe malaria cases in adults. All 6 of the deceased patients in this study suffered cardiopulmonary arrest and died. Postmortem autopsy is not a routine in Yemen; it is only done in legal cases. Five out of the 6 deceased patients in this study (83.3\%) had cerebral malaria and the sixth (16.7\%) had renal failure. However, hematological findings were not seriously deteriorated in the studied patients with cerebral malaria. This finding is similar to that reported by Mengistu and Diro in Ethiopia [15], as well as to the findings of Giha

Table 5. Sex, age, and studied hematological parameters in patients with cerebral malaria.

\section{Patients with cerebral malaria $(n=20)$}

\section{Hematological parameters}

\begin{tabular}{l|l} 
Mean \pm SD & Range
\end{tabular}

\begin{tabular}{|c|c|c|c|}
\hline Sex of patient: & Male & \multicolumn{2}{|c|}{$18(90.0 \%)$} \\
\hline & Female & \multicolumn{2}{|c|}{$2(10.0 \%)$} \\
\hline \multicolumn{2}{|l|}{ Age (years) } & $31.6 \pm 17.0$ & $18-80$ \\
\hline \multicolumn{2}{|c|}{ Hemoglobin concentration (g/dL) } & $11.4 \pm 1.7$ & $9.2-13.8$ \\
\hline \multicolumn{2}{|c|}{ Platelet count $\left(\mathrm{x} 10^{9} / \mathrm{L}\right)$} & $143.5 \pm 52.8$ & $40-373$ \\
\hline \multicolumn{2}{|c|}{ WBC count $\left(\times 10^{9} / \mathrm{L}\right)$} & $5.8 \pm 4.6$ & $1.0-19.0$ \\
\hline
\end{tabular}

Sex of patients expressed as number and percentage. SD: standard deviation; WBC: white blood cell. 
et al. [16] in Sudan, who reported mean hemoglobin levels to be higher in patients who died of severe malaria than in the survivors.

\section{Conclusion}

This study concluded that hematological changes are common complications encountered in any patient with severe malaria. Hemoglobin concentration is associated with significant changes in relation to the type of complications of severe malaria; however, it is not associated with the clinical outcome after severe malaria. The total WBC count cannot be used as a predictor for severity. Thrombocytopenia can implicate complications, but it is usually asymptomatic and platelet transfusions are generally not required because patients recover quickly. It is recommended that physicians should rely on the clinical presentation and complaints of patients with severe malaria and not hurry to conduct transfusion of blood or blood components based on the findings of hematological parameters alone (Table 5).

\section{Conflict of Interest Statement}

The authors of this paper have no conflicts of interest, including specific financial interests, relationships, and/ or affiliations relevant to the subject matter or materials included.

\section{References}

1. Trampuz A, Jereb M, Muzlovic I, Prabhu RM. Clinical review: severe malaria. Crit Care 2003;7:315-323.

2. Svenson JE, MacLean JD, Gyorkos TW, Keystone J. Imported malaria. Clinical presentation and examination of symptomatic travelers. Arch Intern Med 1995;155:861868.

3. [No authors listed.] Severe falciparum malaria. World Health Organization, Communicable Diseases Cluster. Trans R Soc Trop Med Hyg 2000;94(Suppl. 1):1-90.

4. [No authors listed.] Severe and complicated malaria. World Health Organization, Division of Control of Tropical Diseases. Trans R Soc Trop Med Hyg 1990;84(Suppl. 2):1-65.

5. Al-Mekhlafi AM, Mahdy MA, Azazy AA, Fong MY. Molecular epidemiology of Plasmodium species prevalent in Yemen based on 18 s rRNA. Parasit Vectors 2010;3:110.
6. Al-Taiar A, Jaffar S, Assabri A, Al-Habori M, Azazy A, AlMahdi N, Ameen K, Greenwood BM, Whitty CJ. Severe malaria in children in Yemen: two site observational study. BMJ 2006;333:827-832.

7. Al-Mekhlafi AM, Mahdy MA, Azazy AA, Fong MY. Clinical situation of endemic malaria in Yemen. Trop Biomed 2010;27:551-558.

8. Buffet PA, Safeukui I, Milon G, Mercereau-Puijalon O, David $\mathrm{PH}$. Retention of erythrocytes in the spleen: a doubleedged process in human malaria. Curr Opin Hematol 2009;16:157-164.

9. Perkins DJ, Were T, Davenport GC, Kempaiah P, Hittner JB, Ong'echa JM. Severe malarial anemia: innate immunity and pathogenesis. Int J Biol Sci 2011;7:1427-1442.

10. Das BS, Nanda NK, Rath PK, Satapathy RN, Das DB. Anemia in acute Plasmodium falciparum malaria in children from Orissa State, India. Ann Trop Med Parasitol 1999;93:109-118.

11. Bashawri LAM, Mandil AA, Bahnassy AA, Ahmed MA. Malaria: hematological aspects. Ann Saudi Med 2002;22:372-377.

12. Looareesuwan S, Davis JG, Allen DL, Lee SH, Bunnag D, White NJ. Thrombocytopenia in malaria. Southeast Asian J Trop Med Public Health 1992;23:44-50.

13. Banzal S, Ayoola EA, El-Sammani EE. The clinical pattern and complications of severe malaria in the Gizan Region of Saudi Arabia. Ann Saudi Med 1999;19:378-380.

14. Khan SJ, Abbass Y, Marwat MA. Thrombocytopenia as an indicator of malaria in adult population. Malaria Res Treat 2012;2012:405981. doi: 10.1155/2012/405981. Epub 2012 Jul 2.

15. Mengistu G, Diro E. Treatment outcome of severe malaria in adults with emphasis on neurological manifestations at Gondar University Hospital, north west Ethiopia. Ethiop J Health Dev 2006;20:106-111.

16. Giha HA, Elghazali G, A-Elgadir TM, A-Elbasit IE, Eltahir EM, Baraka OZ, Khier MM, Adam I, Troye-Blomberg M, Theander TG, Elbashir MI. Clinical pattern of severe Plasmodium falciparum malaria in Sudan in an area characterized by seasonal and unstable malaria transmission. Transact Royal Soc Trop Med Hyg 2005;99:243-251. 